\title{
Disentangling Facts and Values: an Analysis of Putnam's Pragmatic Ethics
}

\author{
Darlei Dall'Agnol
}

\begin{abstract}
In several important works in ethics, Hillary Putnam criticizes the traditional fact/value dichotomy, which is based on the Humean question whether ought follows from is. More recently, Putnam even declared the collapse of this dichotomy calling once again for rethinking the last dogma of empiricism, namely the positivist creed that facts are objective and values are subjective. The aim of this work is to reassess Putnam's main arguments to show the entanglement between facts and values. Putnam is right in many of his criticisms, but it is not clear also how he avoids reductionist monistic naturalism, which he considers an "inadequate philosophy". Using his pragmatic pluralism inspired by Wittgenstein, I will try to show that we have reasons to make a distinction between facts and values.
\end{abstract}

Keywords: Ethics; facts; values; Putnam.

In this paper, I would like to raise Putnam's question "Why are we tempted by the fact/value dichotomy?" and to examine this issue considering his "entanglement" thesis. Putnam's main idea is that facts and values are entangled, that is, they are interconnected and cannot be separated into two realms (1981, 127f., 201f.; 1992b, 165f.; 2002, p.28-45; 2004, 15f.). I will try to show that we need, in ethics, to disentangle facts and values and argue that they are distinct.

To start with, let's consider the following real life story, which I will put forward as a counterexample to Putnam's entanglement thesis:

Baby Blue was born extremely prematurely (23 weeks). She had infections and was on antibiotics. One month later, she was diagnosed with a potentially fatal intestinal disease, namely NEC (Necrotizing Enterocolitis) in which bowel tissue dies. There was no possibility of survival. The Health Team wanted to provide palliative care only. The parents agreed, but afterwards they found out that the Hospital had withdrawn nutrition. They were Christians and wanted the baby to be kept alive. They were hoping for a miracle. The doctors could do nothing given the clinical conditions and the Hippocratic Oath based on the principle of non-maleficence. The Ethics Committee decided that Baby Blue should not be transferred to another facility for a second opinion. The parents went to Court arguing that only they had the right to decide whether life sustaining treatment should be given or withheld. Just one night before court hearings, which could have resulted in the order to increase her care, Baby Blue passed away.

Principia 17(2): 265-274 (2013).

Published by NEL — Epistemology and Logic Research Group, Federal University of Santa Catarina (UFSC), Brazil. 
If we ask people to say what is factual and what the values in this story are, we will be surprised to find how different the answers might be. Now, in order to see clearly what should have been done in this case, I believe that one must make a clear distinction between facts, which are determined (e.g., Baby Blue has Necrotizing Enterocolitis), and values (e.g., rights), which are open to our choices, for instance, the right to withdraw artificial nutrition and let Baby Blue die or the right to a second opinion. We have here a conflict of values, despite the fact that the persons involved agree upon the facts, which may lead to a real moral disagreement. I think that we must disentangle facts and values in order to recognize the best course of action. Yet Putnam argues that facts and values are always interconnected.

In several important philosophical works touching on ethical issues, from Reason, Truth and History (1981) to Ethics without Ontology (2004), Putnam criticizes the traditional dichotomy between facts and values. Recently, Putnam even declared the collapse of the fact/value dichotomy and called once again for the rethinking of the last dogma of empiricism, namely the positivist creed that facts are objective and values are subjective (2002, p.28f). He points out that for much of the last century philosophy of science was driven by the prejudice that knowledge of facts did not presuppose values. The origin of such a dichotomy was the so-called "Hume's Law", namely "No ought from an is", a law which Putnam, in my opinion, overestimates.

I think that Putnam is right to be against the positivist approach to science, which was supposed to be axiologically neutral. Thus, one of Putnam's first strategies to demonstrate the entanglement of facts and values, held in his book Reason, Truth and History, as he himself recognizes, was not a new one: he rehabilitates the view that "... the practices of scientific inquiry upon which we rely to decide what is and what is not a fact, presupposes values." (1981, p.128). His intention was to show that values such as coherence, simplicity etc. inform our scientific inquiries. In other words, science is not, pace positivists, a value-free enterprise, but it is value-laden. I think that Putnam is right to criticize the empiricist and positivist conception of "fact" insisting that there are epistemic values guiding scientific and philosophical activities. Thus, on this point, I agree with Putnam: considering the story of Baby Blue, Medicine is certainly a scientific practice guided by values, for instance, by the value of beneficence or, at least, of doing no harm. The good to be sought is health, which is certainly part of our wellbeing. That is to say, scientific rationality is itself, to quote Putnam "... part of our idea of human cognitive flourishing" (1991, p.134) or "part of our idea of the good" (1991, p.137). I will not dispute this point. But his argument, as Putnam himself recognizes, does not show that all values are necessarily interconnected with facts.

I agree with Putnam on another point. The meta-ethical results of the positivist creed were the many forms of non-cognitivism (e.g., Emotivism, Prescritivism etc.) in moral epistemology, some of which come quite close to considering moral judgments 
simply irrational. In this sense, Putnam also has a good point in calling attention to the need to overcome this meta-ethical approach. His diagnosis of why philosophers and scientists were led to postulate such a dichotomy is, most of the time, right, especially with regards to the mistake that has been made by logical positivists who believe that ethical statements are unverifiable, and, therefore, meaningless. Alfred Ayer was a positivist in epistemology and an Emotivist in meta-ethics. Stevenson, Hare and others were non-cognitivists. Thus, I also agree with Putnam that we need a better moral epistemology. I will return to this point later. On the other hand, Putnam did not convince me that there is no need for a distinction (if not a complete separation) between facts and values and, in fact, I believe that to conflate them is philosophically misleading and even dangerous from a practical point of view. As we will see, Baby Blue's story reveals exactly this point.

Let me start by questioning one positive argument Putnam uses to show us that facts and values are entangled. This is his analysis of "thick ethical concepts", a point also developed by Iris Murdoch and Bernard Williams, as being composed of both descriptive and normative elements that are somewhat interconnected. Putnam disagrees with philosophers such are Richard Hare, who believed otherwise. I am afraid, on this point, I am with Hare and not with the patron of this symposium: even if some values are supervenient to facts, they are not reducible to them. To recognize this point, suppose someone says that letting Baby Blue die was "cruel". Now ask yourself whether this shows that "cruelty" is not only a descriptive, but also a prescriptive or an evaluative word and whether these elements are necessarily entangled. Suppose that a member of the Health Team disagrees that it is cruel to let Baby Blue die, holding that it is the best way of dealing with the situation. Is she right? Would direct killing be better? Was Baby Blue's mother wrong in saying that it was cruel? It seems that we do not have a clear and univocal answer to whether letting die is cruel or not. The reason is that we have different moral systems, divergent moralities. Pace Putnam, therefore, we may "agree on the facts and disagree about values" and that is one reason for disentangling them. We do indeed have two world views in conflict here: a scientific and a religious one giving rise to distinct moral systems. To think that there is just one single and right answer is philosophically misleading. That would only be possible under a reductionist analysis, a point Putnam apparently rejects.

It is not clear, however, how Putnam avoids such reductionism, that is, the idea that "... monistic naturalism (or "physicalism") is an inadequate philosophy" (1981, p.211). One reason may be related to Hume's Law. But consider the Baby Blue story again and the following problem: suppose an argument where premise one is this descriptive sentence:

(1) Baby Blue's intestine is dead.

Principia 17(2): 265-274 (2013). 
and ask yourself which of the following sentences can be inferred from it:

(2) The Health Team ought to withdraw nutrition.

or

(3) The Health Team ought to respect the parents' right to a second opinion.

If one holds that a single ought follows from an is, against Hume's Law, she must be able to prove to us unequivocally whether (2) or (3) can be inferred from (1). If this cannot be done, it shows that facts and values are not entangled. This means that Hume's Law is essentially correct and that facts and values cannot be conflated.

Let me now examine Putnam's reasons for rejecting other pro-distinction arguments between facts and values - not only the positivist misconceptions on this issue. At the end of his book Reason, Truth and History, Putnam argued that G. E. Moore's famous "Naturalistic Fallacy" (which must not be confused with Hume's Law) failed to show us that ethical concepts are not reducible to natural ones. Moore's argument was faulty, according to Putnam, because it does not leave room for the existence of his "synthetic identity of properties" (Water is $\mathrm{H}_{2} \mathrm{O}$ ) or for the Kripkean "epistemically contingent necessary truths" (the evening start is the morning start) (1981, p.207). Putnam, however, thought that Moore was right in holding that "good" and other ethical concepts are not identical to physical properties. In his own words:

... I think Moore was right (even if his arguments are not acceptable) in holding that 'good', 'right' (and also 'justified belief', 'refers', and 'true') are not identical with physicalist properties and relations. What this shows is not that goodness, rightness, epistemic justification, reference, and truth do not exist, but that monistic naturalism (or 'physicalism') is an inadequate philosophy (1991, p.211)

What Putnam is saying here is that Moore's philosophical worldview was the right one, but that his arguments to maintain it had gone wrong. I will now reconstruct and assess Putnam's objections to Moore.

Putnam presents the following reconstruction of the Naturalistic Fallacy:

Moore's argument that Good cannot be a physicalistic property (a 'natural' property) was that if 'Good' is the same property as 'conducive to maximizing total utility' (or whatever natural property, physical or functional, you care to substitute), then

(1) 'this action is not good even though it is conducive to maximizing total utility'

is a self-contradictory statement (not just a false one). (1981, p.206)

Principia 17(2): 265-274 (2013). 
Now, several remarks need to be made here: first, Moore never wrote 'good' with a capital G, so Putnam seems to be attributing to the author of Principia Ethica a kind of moral realism, namely a Platonic or transcendent one, which is incompatible with his ethics; second, what Putnam is above reconstructing is, in fact, Moore's Open Question Argument and not his Naturalistic Fallacy Argument. Despite the fact that the first point is not of utmost importance here, the second one is. The Open Question Argument was intended to show that the concept of good is indefinable, a primitive notion. If this were correct, then any definition of 'good', either a naturalistic or a metaphysical one, would be mistaken. I believe Putnam overlooks this point, but he is right in pointing out that the Open Question Argument, if it were sound, would prove too much, for instance, it could even prove that "temperature" is not "mean molecular kinetic energy" or that "water" is not " $\mathrm{H}_{2} \mathrm{O}$ ". We should then close the Open Question Argument, that is, not address it.

Let me also say that I do agree with Putnam's project of doing "Ethics without Ontology", (2004) especially his objections against "inflationary" ontologists (I would prefer to say "Ethics without Metaphysics"). His criticism of Platonic metaphysics using Kant and Wittgenstein is philosophically sound, namely there is no need to postulate mysterious objects behind our moral statements. Transcendent Realism is misconceived, that is, there is no point in asking whether there are moral facts "out there" independent of us. Instead of Ontology (with Capital "O”), Putnam develops his pragmatic pluralism, which will be considered soon. But, I believe that Putnam's criticism to Moore as a Platonist is mistaken: Moore was also an adversary of metaphysical explanations of goodness. Moreover, we do need some ontological distinctions and, as Moore correctly insisted, moral properties are different in kind from natural/physical ones, a point with which Wittgenstein agrees. In other words, values are not entangled with facts.

I believe that there is a specific version of the Naturalistic Fallacy argument that can be used to show that ethical terms such as 'good', 'right' and so on cannot be reduced to natural ones (and to metaphysical ones). Ethics, according to Moore, is autonomous: it is not a natural science, but it also does not depend on religion. Considering the Baby Blue story again, to deny that a single ought (either 2 or 3) necessarily follows from an is (premise (1): the fact of NEC) does not imply that we must subscribe any kind of metaphysical value either. That is to say, it is possible to reconstruct the Naturalistic Fallacy based on the notion of category mistake showing that science (which states facts), ethics (which deals with values) and metaphysics (which postulates supersensible entities) are distinct in kind. I will not develop this point here, but this is one more reason to disentangle facts and values. Instead, since Putnam is making a friendly criticism to Moore's philosophy and agrees with him against naturalism or physicalism (at least, in Reason, Truth and History), I will ask whether he has a better antireductionist argument.

Principia 17(2): 265-274 (2013). 
Putnam believes that he has an argument against reductionism (1981, p.114), which relies on his objection to the naturalistic explanations of reference presented at the end of Chapter 2 of Reason, Truth and History. The argument starts by assuming the naturalistic view in these terms: suppose

\section{(1) $x$ refers to $y$ if and only if $x$ bears $R$ to $y$}

is true, where $\mathrm{R}$ is a relation definable in natural science vocabulary without using any semantic notions (1981, p.45). But if reference is determined by theoretical constraints only, then, Putnam argues, “... the reference of ' $x$ bears $\mathrm{R}$ to $y$ ' is itself indeterminate, and so knowing that (1) is true will not help." (1981, p.46) The conclusion is that "... the fact that $\mathrm{R}$ is reference must be a metaphysically unexplainable fact, a kind of primitive, surd, metaphysical truth." (1981, p.46). Thus, a naturalistic view is, according to Putnam, simply a magical theory of reference.

I do not think that Putnam is in a better position here than Moore's Open Question Argument was. It is not enough to point out that an argument is using something as primitive in order to refute it; any argument does precisely that. Moreover, Putnam's criticism to naturalism looks obscure to me. Does it follow from this that we do not need a clear distinction (if not a dichotomy) between what is normative and what is factual? I do not think so: I believe that one problem in the Baby Blue story, which led to litigation was that the Health Team thought that the only "ought" that followed from (1) was (2), and this was based on an inadequate philosophy, namely monistic naturalism. If we are truly pluralists supporting democratic values, as Putnam claims to be, we have to take moral disagreement more seriously. Pluralism is evidence that we need to build up a Commonly Sharable Morality, which allows for some degree of disagreement about values while establishing a solid ground for the co-existence of different moral systems. I will return to this point soon.

Putnam, fortunately, uses a better strategy, which he calls "pragmatic pluralism", to show that values are not subjective or irrational. This appears to be the best of his arguments: the "Wittgensteinian" view (2002, p.33; 2005, p.21), which holds that there are many sorts of statements (many language games) that are not descriptions and yet are under rational control (are reasonable or warranted etc.), including ethical judgments. I believe, however, that there is something missing in Putnam's Wittgensteinianism. For one thing, Wittgenstein is not a pragmatist. Thus, Putnam's view needs to be fostered in order to avoid conflating facts and values but, more importantly, not reducing the latter to the former.

He states pragmatic pluralism in the following way:

... the recognition that it is no accident that in everyday language we employ many different kinds of discourses, discourses subject to different standards and possessing different sorts of applications, with different logical

Principia 17(2): 265-274 (2013). 
and grammatical features - different "language games" in Wittgenstein's sense - no accident because it is an illusion that there could be just one sort of language game which could be sufficient for the description of all of reality! (2004, p.21-2)

As is well known, Wittgenstein's philosophy of language has had an enduring influence on Putnam's work (1981; 1992; 1992b; 2002; 2004). Here, Putnam uses a Wittgensteinian strategy to show that we do indeed have different types of language games. But, then, the question is whether a Wittgensteinian antireductionist argument does not lead to the fact/value distinction.

Consider again the Baby Blue story: the Heath Team was playing a scientific game; the parents were playing a religious game; the Ethics Committee (the Courts) were playing a ethics game: the plurality of language games shows that values and facts are distinct, that is, they belong to different kinds. Thus, the entanglement thesis still sounds like a symptom of scientificism after all. Pace Putnam, it is not enough to distinguish kinds of language games in order to produce an argument against reductive naturalism. It is necessary to show that they are irreducible. Conflating language games, as Wittgenstein repeatedly pointed out, produces metaphysical statements: language goes on holiday, that is, it does not work properly (Wittgenstein, PI, § 28). Thus, we cannot apply rules guiding the use of factual statements to evaluative ones without misusing language. This is one more reason to disentangle facts and values: conflating them produces metaphysical statements.

If we take, now, a close look at the book The Collapse of the Fact/Value Dichotomy, especially at the chapter "The Entanglement of Fact and Value", we realize that Putnam is no longer saying that fact and value are not distinct, but he is only criticizing the dichotomy between facts, which are supposedly objective, and values, which are supposedly subjective (2002, p.9). This point was not clearly presented in his previous works. For instance, in his Realism with a Human Face, Putnam apparently does make a distinction to lead to a dichotomy (1992b, p.167). Moreover, Putnam is now mainly criticizing noncognitivists for relying on a separation between statements, and for considering statements of facts cognitive and statements of values emotive, irrational nonsense. In order to do that, Putnam again uses a "Wittgensteinian" argument (better, a pragmatic one) to show that there are many sorts of statements and that we have to stop equating objectivity with description. There is, so to speak, objectivity without objects (2004, p.52f.)

If this is the case, then it seems clear to me that there are also values which are not entangled with facts. Consider, for instance, Putnam's own analysis of some values in chapter 10 "The Place of Facts in a World of Values" of Realism with a Human Face, namely freedom, rationality etc. (1992b, p.143). The domain of freedom, the idea that we could have done otherwise if we had chosen to do so, is not related to any particular empirical fact. Thus, it looks as if facts and values are disentangled 
after all. That does not mean that values are "queer" metaphysical entities. Values are values and not something else: this was the spirit of Principia Ethica's motto.

This conclusion can then be stated in Putnam's own terms:

If we disinflate the fact/value dichotomy, what we get is this: there is a distinction to be drawn (one that is useful in some contexts) between ethical judgments and other sorts of judgments. (...) But nothing metaphysical follows from the existence of a fact/value distinction in this (modest) sense. (2002, p.19, italics in the original)

However, neither Moore nor Wittgenstein wanted a metaphysical dichotomy between two realms leading to Platonism; yet they made a distinction between facts and values. Ethics is different in kind from religion and from science.

As can be seen, Putnam himself came to recognize the need for not conflating facts and values. So, if the "entanglement thesis" amounts to denying the dichotomy between facts and values, but not the need for a distinction between them, there is no need for any great concern, except whether this "semantic point" has different implications for Putnam's pragmatic ethics.

To finish, then, I would like to go back to the question: why are we after all tempted by the fact/value dichotomy? Granted, if it leads to an inflated Ontology (with Platonic entities), we must reject it as Putnam did, especially if it misrepresents the nature of values. If it leads to the placing of all values outside the realm of rational argument (a noncognitivist meta-ethics), we must also reject it as Putnam did. But we may have good reasons for holding the moderate version of the distinction between facts and values, especially if it avoids an ontology based exclusively on facts, facts, facts, that is, naturalism in its monistic version, physicalism. Values may have different sources (scientific practices, but also religion, philosophical reflection and so on) and to recall the story of Baby Blue, we do have a real disagreement between the Health Team and the parents not on the clinical facts of the story, but more importantly on values. If we are truly pluralist, we must recognize that values are part of a rich ontology, and a democratic society is expected to respect them where the Health Team did not.

One reason to be attracted to the fact/value dichotomy is, as Putnam points out (2002, p.44), the idea that no plausible explanation of the possibility of ethical knowledge has been presented so far in philosophy. This was Williams' point: there is no way of explaining how ethical knowledge is possible in "absolute" terms, that is, how moral thought, belief, reference are possible. Here, however, it seems that a very important possibility was left out by Putnam and many others: part of the empiricist and positivist creed was that there is knowledge only if we have justified true beliefs, that is, knowledge of one kind only, namely knowing-that. Actually, there is a different kind of knowledge, as Wittgenstein pointed out (PI, § 151-2) where "knowing" 
means is able to, that is, capable of doing something. I used this kind of knowledge, namely knowing-how as the basic foundation for a new moral epistemology, which I called "Practical Cognitivism". For instance, a person needs to know how to care for a vulnerable individual (because it is good for her, but also respectfully), know how to respect a person (deferring to her rights because they are her rights) and so on. I would like then to suggest that one promising way of recognizing that facts and values are not always entangled is to see values as the ontological counterpoint of knowing-how and facts, the ontological side of knowing-that. This is not to subscribe any inflated Ontology, but only to distinguish different kinds of entities: what kind of object something is, says Wittgenstein, is determined by grammar.

Finally, I would like to point out that I partially agree with Putnam's non-relativism:

... if we give up the very idea of a "rationally irresolvable" ethical dispute, we are not thereby committing ourselves to the prospect of actually resolving all our ethical disagreements, but we are committing ourselves to the idea that there is always the possibility of further discussion and further examination of any disputed issue ... (2002, p.44)

Thus, the plurality of moral systems, the diversity of moral opinions, the real disagreement about particular moral issues must not prevent us from building up a Commonly Sharable Morality, a public system of rules which apply to everyone equally, establishing the moral requirements of care and respect. This is a morality that is the condition to make possible a reasonable moral pluralism, which must be presupposed if we allow for a second opinion in the Baby Blue story or for a different outcome once NEC was found: a caring mother may not want to see her baby starving. Thus, if we accept pluralism, then both a naturalist and non-naturalist stand on an equal basis and need to know how to respect each other.

\section{References}

Moore, G. E. 1993. Principia Ethica. Revised Edition. Cambridge: Cambridge University Press. Putnam, H. 1981[1991]. Reason, Truth and History. Cambridge: Cambridge University Press.

- 1992a. Renewing Philosophy. Cambridge, Mass.: Harvard University Press.

- 1992b. Realism with a Human Face. Cambridge, Mass.: Harvard University Press.

- 2002. The Collapse of the fact/value dichotomy and other essays. Cambridge, Mass.: Harvard University Press.

- 2005. Ethics without Ontology. Cambridge, Mass.: Harvard University Press.

Wittgenstein, L. 1968. Werkausgabe. Frankfurt am Main: Suhrkamp.

Principia 17(2): 265-274 (2013). 


\section{Darlei Dall'Agnol Departamento de Filosofia Universidade Federal de Santa Catarina/CNPq \\ Florianópolis, SC BRASIL \\ ddarlei@yahoo.com}

Resumo. Em várias obras importantes na ética, Hillary Putnam criticou a dicotomia tradicional entre fatos e valores a qual está baseada na questão humeana de saber se dever segue-se de ser. Recentemente, Putnam declarou até mesmo o colapso dessa dicotomia e clamou novamente para se repensar o último dogma do empiricismo, a saber, a crença positivista de que fatos são objetivos e valores subjetivos. O objetivo deste trabalho é reavaliar os seus principais argumentos para mostrar que fatos e valores então entrelaçados. Putnam está certo em muitas de suas críticas, mas também não é muito claro como ele evita o naturalismo monista reducionista, que ele considera uma "filosofia inadequada". Usando o seu pluralismo pragmático inspirado em Wittgenstein, vou procurar mostrar que há boas razões para manter uma distinção entre fatos e valores.

Palavras-chave: Ética; fatos; valores; Putnam. 